\title{
The moderating role of lean operations between supply chain integration and operational performance in Saudi manufacturing organizations
}

\author{
Jehad S. Bani Hani ${ }^{a^{*}}$
}

${ }^{a}$ Department of Health Services and Hospitals Management, Collage of Business, University of Jeddah, Saudi Arabia

\begin{tabular}{l}
\hline C H R O N I C L E \\
\hline Article history: \\
Received August 15, 2020 \\
Received in revised format \\
September 8, 2020 \\
Accepted October 92020 \\
Available online \\
October 92020 \\
\hline Keywords: \\
Supply Chain \\
Supply Chain Integration \\
Lean Operations \\
Operational Performance \\
Saudi Manufacturing Sector \\
SEM Model
\end{tabular}

\section{A B S T R A C T}

\begin{abstract}
The fundamental reason for this study was to explore the impact of Supply Chain Integration on Operational Performance through the directing part of Lean Operations. The study essential information gathered from the example that contains 288 supervisors working in Saudi Industrial Organizations lied in the western locale, utilizing an all-around planned survey. This study coordinated to study how the supply chain integration, lean operations, and operational performance can impact each other in manufacturing associations. SEM model created and deliberately surveyed and tried. The key discoveries demonstrate that rehearsing supply chain integration cycles could bring about expanding the open door for manufacturing associations to accomplish operational performance through applying lean practices. Therefore, the connection between supply chain integration and operational performance, just as the connection between lean operations and operational performance, was positive, given these connections, it very well may be presumed that the lean operations (as a directing variable) can have a positive impact the connection between supply chain integration and operational performance. Particularly, the connection between supply chain integration and quality performance measures.
\end{abstract}

(C) 2021 by the authors; license Growing Science, Canada.

\section{Introduction}

Supply chain integration is the center of supply chain management, which is likewise a significant technique for the feasible improvement of ventures. Supply chain management is the integration of key business measures from the end-user through unique providers that gives items, administrations, and data that include an incentive for clients and different partners (Rajagopal et al., 2016). Supply chain integration has gotten expanding enthusiasm from researchers, researchers, and professionals as of late, as it is a useful system to decrease exchange costs through building long haul connections and incorporating between hierarchical cycles (Zhao et al., 2002, 2008). The supply chain integration methodology makes an incentive for an association's clients and brings providers and clients into the worth creation measure (Tan \& Kannan, 1998; Vickery et al., 2003). As of late, Das et al. (2006) and Germain et al. (2008) reexamined the expected beneficial outcome of supply chain integration on performance. Das et al. (2006) demonstrated that expanding integration with providers over a specific edge esteem does not bring about improved performance. They additionally upheld the possibility that an ideal arrangement of integration rehearses exists. As of late, the genuine contenders are the supply chain integration as opposed to singular associations (Aljawarneh \& Atan, 2018). The operational performance of manufacturing associations is affected by supply chain integration rehearses, which are viewed as basic to performance improvement in any association (Truong et al., 2017). Four practices in the supply chain management build are long haul connections, data sharing, participation, and cycle integration have a positive and huge relationship with all elements of operational performance (De Souza Miguel et al., 2011). As indicated by Tatoglu et al. (2016), supply chain integration rehearses significantly affect the operational performance of little and medium endeavors (SMEs). The proposed directing variable in this study is lean operations. Lean activity is an operational system that planned to accomplish smooth creation stream by killing waste and by expanding the exercises esteem (Aljawarneh \& Al-Omari, 2018). Associations are roused to receive lean operations as a procedure, to

* Corresponding author

E-mail address: jbanihani057@gmail.com (J. S. Bani Hani)

(C) 2021 by the authors; licensee Growing Science. doi: $10.5267 /$ j.uscm.2020.10.004 
keep on around the world serious (Subashini \& Kumar, 2013; Solaimani, 2019). The associations that overlook the lean procedure would not have the option to have an open door against the current worldwide rivalry for greater, quicker conveyance, and lower costs (Flott, 2002; Srinivasaraghavan \& Allada, 2006; Habidin et al., 2012). Operational performance determines organizational performance (Al-Omari, et al., 2020). The operations in a manufacturing organization ought to be proficient and successful so as to accomplish organizational objectives (Masa'd \& Aljawarneh, 2020). Operational performance (OP) is the arrangement of all specialty units inside an organization to guarantee that they are cooperating to accomplish center business objectives.

The research on the issues of supply chain integration, operational performance, and lean operations are interesting issues, especially the connections among these goals (Al-Omari et al., 2018). Thusly, the fundamental motivation behind this study was to examine the connection between supply chain integration and operational performance with the directing part of lean operations in Saudi manufacturing organizations (Alzoubi et al., 2020).

\section{Literature review}

\subsection{Supply Chain Integration}

The supply chain is an interrelated arrangement of processes inside and across organizations, which creates an assistance or item as per the general inclination of customers (Krajewski et al., 2019). A supply chain can be portrayed as a progression of firms, which incorporate providers, wholesalers, and the end customers who might be associated with various processes and exercises to deliver items and administrations for both upstream and downstream customers (Lofti et al. 2013). The target of the supply chain is to structure the supply chain to boost its upper hand and advantages to a definitive buyer (Heizer, Render, and Munson, 2017). Supply chain integration characterized as the connection and coordinated effort between supply chain accomplices that mean to shape an organization (Huang et al., 2014). A supply chain network is viewed as an unpredictable sources of info/yields network framework, in which input components will be changed into yield components through the reason for the organization structure (Long 2014). As indicated by Van der Vaart et al. (2007), supply chain integration is how much a producer deliberately teams up with its supply chain accomplices and cooperatively oversees Intra-and between organization processes to accomplish powerful and proficient progressions of items and administrations, data, cash, and choices, to give greatest incentive to the client easily and fast (Van der Vaart et al., 2007). Supply chain integration has a few noteworthy levels (1) vital joint effort between associations so as to accomplish commonly gainful vital objectives that dependent on contract span, sharing of data, and cooperation in compromise (Flynn et al., 2010). (2) Coordination of operational processes inside the organization and between accomplices (Errassafi et al., 2019).

\subsection{Operational Performance}

Operational performance (OP) is the arrangement of all specialty units inside an organization to guarantee that they are cooperating to accomplish center business objectives. As per past investigations, operational performance alludes to the adaptability, conveyance time, request proficiency, and stock turnover of organizations (Adams et al., 2014; Freeman \& Styles, 2014; Liu et al., 2016), which are significant approaches to continue upper hands. Operational performance indicates the quantifiable features of an organization's processes, for example, unwavering quality and creation process duration results (Voss et al., 1997). Operational performance characterized as the performance identified with organizations' inside operations, for example, profitability, new item advancement, serious needs, and consumer loyalty (Ahmad and Schroeder, 2003; Feng et al., 2006). Operational Performance additionally alluded to as the blend of a lot of processes and an improvement procedure that together assist organizations with advancing their business performance (Bani Hani \& Alomari, 2014). This study estimates operational performance by utilizing the accompanying builds that were created by Baird et al. (2011). Quality performance gauges, that incorporate improved item/administration quality, expanded profitability, diminished expenses of deformities and modify, decreased conveyance lead season of completed items/administrations to customers, decreased client objections, improved consumer loyalty level, and a decrease in the quantity of guarantee claims. (2) Inventory management performance: buy material turnover, all out stock turnover, and decreased stock out of date quality costs (Al-Jawarneh, 2016).

\subsection{The Direct Influence of Supply Chain Integration on Operational Performance}

Supply chain integration incorporates inner integration and outer integration. Inward integration alludes to the integration of streams and processes and working together inside the manufacturing organization (Errassafi et al., 2019). Inner integration characterized by Flynn et al. (2010), as the degree to which an organization creates organizational techniques, practices, and processes that can be synchronized so as to guarantee that they increase the value of the organization's customers (Banyhamdan et al., 2020). Inner integration alludes to the integration of departmental capacities and exercises so as to improve performance across departmental limits, increment client support levels, and guarantee an upper hand (Basnet 2013). By applying supply chain inside integration, organizations can accomplish operational performance objectives identified with quality performance and stock performance. Hence, the researcher guesses that:

Hla: Supply chain internal integration positively influences Quality performance measures.

H1b Supply chain internal integration positively influences Inventory management performance. 
External integration as the second segment of supply chain integration alludes to the coordination of operational processes inside the organization and between accomplices, through a twofold point of view, incorporates client integration and provider integration (Flynn et al., 2010; Petersen, Handfield, \& Ragatz, 2005). The supply chain outer integration speaks to how much a producer accomplice with its outside accomplices to structure between organizational methodologies, practices, and processes into cooperative, synchronized processes Studies show that supply chain integration positively affects improving organizations' corporate performance and making upper hand (Danese \& Romano 2010; Stank et al., 2001). Outer integration gives the fundamental client arranged help for interior integration, empowering endeavor transportation arranging, and cycle control to address market issues in a convenient way (Ji et al., 2019). Both outer and interior integration is urgent to guarantee a synchronized and consistent progression of assets inside and over the supply chain principally in the manufacturing business (Sundram et al., 2019). By executing supply chain outer integration, organizations can accomplish operational performance objectives identified with quality performance and stock performance. In this way, the researcher conjectures that:

H1c: Supply chain internal integration positively influences Quality performance measures.

H1d: Supply chain internal integration positively influences Inventory management performance.

\subsection{The Moderating influence of the Lean Operations}

Lean operations is a system of manufacturing that centers around conveying the most excellent item on schedule and at the least cost (Liker and Wu, 2000; Lin \& Wu, 2014). As per Worley (2004), lean operations are the orderly evacuation of waste by all individuals from the association from all zones of the worth stream (Mahafzah et al., 2020). Lean operations portrayed as a decreased degree of information assets in the creation framework for a given degree of output by eliminating waste (Muda) from the framework (Lewis, 2000; her bach, et al., 2017; Al-Da'abseh, et al., 2018). A lean manufacturing framework is a lot of instruments/methods to distinguish and eliminate waste (Anvari, et al., 2010). The appropriation of the lean methodology will change nearly everything in each industry-decisions for purchasers, the personality of work, and fortune of the business by joining the advantages of capacities and colossal creation (Womack and Jones, 1990). The Lean manufacturing approach contains a few standards and practices, which need to get upgraded effectiveness, quality, and attention to clients (Rose et al., 2014). Yadav et al. (2010) created ten standards for lean operations based on comprehensive writing audit and writers' modern experience, which further utilized for examination of lean execution (Chaple1 et al., 2014). The connection between supply chain integration and operational performance can be investigated by the various types of lean operations.

For this investigation, it is essential to quantify the degree to which lean operations moderate the connection between supply chain integration and operational performance, contingent upon the basic ten lean standards recognized by Shah and Ward (2007) to gauge the condition of lean implementation in organizations. Thus, the researcher hypothesizes that:

$\mathrm{H}_{2}$. Supply chain integration positively influences lean operations.

$\mathrm{H}_{2 \mathrm{a}}$ : Supply chain internal integration positively influences lean operations.

$\mathrm{H}_{2 \mathrm{~b}}$ : Supply chain external integration positively influences lean operations.

$\mathrm{H}_{3}$. Lean operations positively influence operational performance.

$\mathrm{H}_{3 \mathrm{a}}$ : Lean operations positively influence quality performance measures.

$\mathrm{H}_{3 \mathrm{~b}}$ : Lean operations positively influence inventory management performance.

H4: Lean operations moderate the influence of supply chain integration on Operational Performance.

H4a: Lean operations moderate the influence of supply chain internal integration on Quality performance.

$\mathrm{H} 4 \mathrm{~b}$ : Lean operations moderate the influence of the supply chain internal integration on Inventory management performance.

H4c: Lean operations moderate the influence of supply chain external integration on Quality performance measures.

H4d: Lean operations moderate the influence of supply chain external integration on Inventory management performance.

\subsection{Conceptual Framework}

Directing consequences for the connection between the autonomous and ward factors have pulled to numerous researchers' interest. The primary motivation behind this study was to research the connection between Supply Chain Integration and Operational Performance with the intervening part of Lean Manufacturing Principles in Saudi manufacturing organizations. To this end, the connections between these three factors had first been inspected in an in pairs way, and afterward the intervening part of lean manufacturing standards in the relationship of the other two factors was surveyed, it ought to be noticed that the accompanying model is considered among the factors (Fig. 1). 


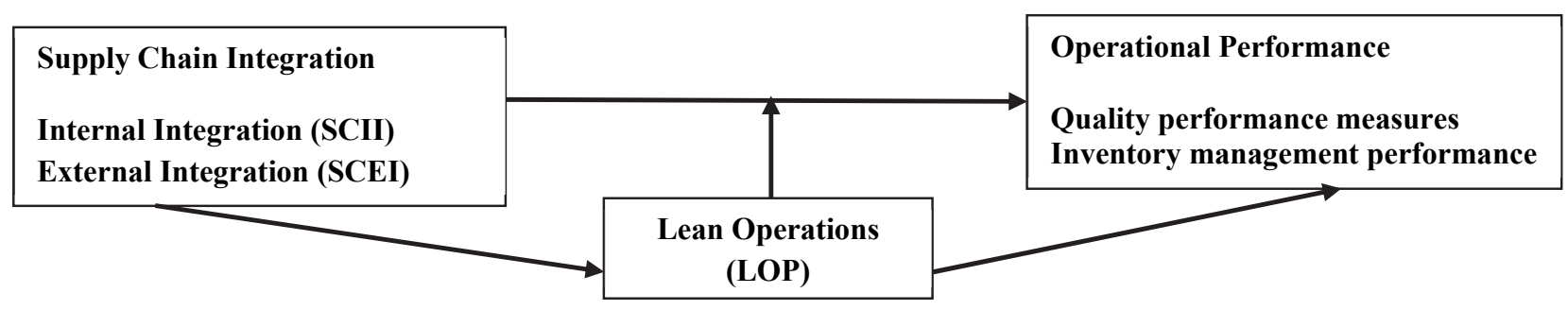

\section{Research methodology}

Fig. 1. The Conceptual Model of Research

The model of this study is an interpretive one and the study is applied-distinct research. The study contains a deductive methodology since the outcome has been gotten by assembling the acknowledged real factors. Also, the examination strategy depends on an examination from an all-encompassing perspective toward the subtleties, and in this way, the quantitative technique has been utilized (Alshare et al., 2020). The study is field research and an unmistakable study has been used as the research procedure. Also, the information has been accumulated utilizing the survey (al-Bourne et al., 2020). The poll contains four sets. The previously set incorporates the respondents' segment attributes: age, instruction, position, and experience. The second set things depended on Errassafi et al. (2019) model that incorporates 16 markers reflecting supply chain interior integration, and supply chain outside (provider) integration. The third set incorporates 10 things created dependent on Shah and Ward (2007) model that incorporates 10 variables utilized and examined to gauge the lean operations. The last set incorporates 10 things to gauge operational performance dependent on a study of Baird et al. (2011). All develops were estimated utilizing a five-point Likert scale. Also, included scores of low, low, medium, high, and extremely high, separately, from one to five. The objective populace for this study included all administrators working in Saudi manufacturing organizations situated in the western area of Saudi Arabia. An absolute number of (300) administrators were picked arbitrarily from the population. (288) usable polls were gotten showing a reaction pace of $96 \%$. Zero in on a solitary industry empowers the researcher to more readily comprehend the processes and practices, which encourages correlation among firms (Tsikriktsis, 2007).

\subsection{Data Analysis and Hypotheses Tests}

In other to analyze the accumulated data, both illuminating and inferential experiences have been used. Moreover, One Sample T-test has been used for examining data and examination theories and for recognizing the status of exploration factors; meanwhile, Confirmatory Factor Analysis has been utilized for assessing the foreordained model. Finally, Structural Equation Modeling (SEM) applied for testing the exploration speculations. Kolmogorov-Smirnov test (K-S test) moreover used for testing the commonness of data. Plus, the exploration speculations have been taken a stab at using the Spearman Correlation Test ensuing to certifying the applied scale and in doing in that capacity, SPSS and PLS writing computer programs are used for examination. For investigating data, the authentic association techniques like straight backslide have been utilized.

\section{Findings}

\subsection{Respondents' Demographic Characteristics}

A total of 288 respondents responded fully to the questionnaire. A detailed description of the respondents' demographic statistics is presented in Fig. 2.

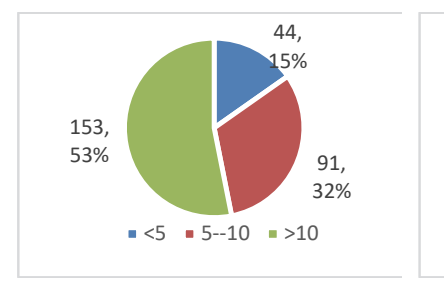

Experience

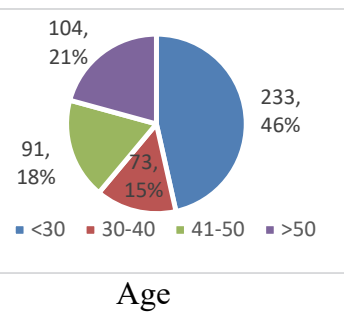

Fig. 1. Chard

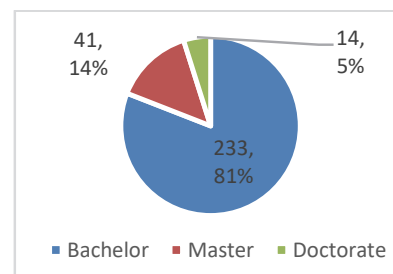

Education

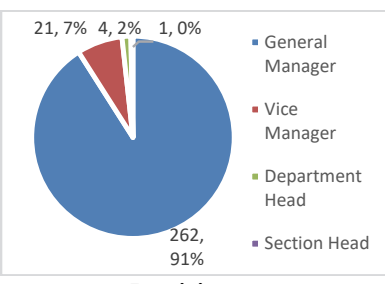

Position

\subsection{Descriptive Statistics for Study Variables}

The clear insights of the factors are appeared in Table 1. The mean an incentive for the supply chain integration segments lied between 4.71 for inner integration, and 4.53 for outside integration, the standard deviation lies between (0.57-0.69), The mean an incentive for lean operations parts lie between the most elevated mean 4.63 for representative contribution and the least mean 3.56 for complete gainful/preventive upkeep, the standard deviation lies between (0.44-0.83). The mean an incentive for operational performance factors lied between 4.56 for Quality performance measures and 4.53 for Inventory management performance, the standard deviation lies between $(0.48-0.59)$, The estimations of standard deviation implies 
that the information was more focused or homogeneous on the grounds that the degree of inconstancy or scattering was littler.

Table 1

Descriptive Statistics for Study Variables

\begin{tabular}{|c|c|c|c|}
\hline Variable & Components & Mean & STD \\
\hline \multirow{2}{*}{ Supply Chain Integration } & Internal & 4.71 & 0.57 \\
\hline & Eternal & 4.53 & 0.69 \\
\hline \multirow{10}{*}{ Lean operations } & 1. Supplier feedback & 4.21 & 0.61 \\
\hline & 2. JIT & 4.58 & 0.73 \\
\hline & 3. Supplier development & 4.57 & 0.48 \\
\hline & 4. Customer involvement & 4.39 & 0.49 \\
\hline & 5. Pull (PULL): & 3.78 & 0.55 \\
\hline & 6. Continuous flow & 4.32 & 0.69 \\
\hline & 7. Set up time reduction & 3,71 & 0.59 \\
\hline & 8. Total productive/preventive maintenance & 3.56 & 0.44 \\
\hline & 9. Statistical process control & 4.47 & 0.70 \\
\hline & 10. Employee involvement & 4.63 & 0.83 \\
\hline \multirow{2}{*}{ Operational Performance } & Quality performance measures & 4.56 & 0.48 \\
\hline & Inventory management performance & 4.53 & 0.59 \\
\hline
\end{tabular}

\subsection{Model Assessment}

\subsubsection{Instrument Reliability \& Validity}

The dependability of the questionnaire was estimated utilizing Cronbach's Alpha coefficient (Table 2) the unwavering quality of each build have Cronbach's Alpha records more noteworthy than the proposed esteem (0.7), which is viewed as adequate and demonstrating that the study instrument was created with acceptable interior consistency (Nannully, and Berstein, 1994; Hair, et al., 2013).

Table 2

Hypothesized Model Reliability \& Validity Indices'

\begin{tabular}{|c|c|c|c|c|c|c|c|c|}
\hline Variable & Item & Loading & Cronbach's Alpha & $\mathrm{CR}$ & AVE & MSV & ASV & $\mathbf{R}^{2}$ \\
\hline \multirow{5}{*}{$\begin{array}{c}\text { SCII } \\
,\end{array}$} & SCII1 & 0.680 & \multirow{5}{*}{0.937} & \multirow{5}{*}{0.931} & \multirow{5}{*}{0.675} & \multirow{5}{*}{0.573} & \multirow{5}{*}{0.347} & \\
\hline & SCII2 & 0.745 & & & & & & \\
\hline & SCII3 & 0.846 & & & & & & \\
\hline & SCII4 & 0.960 & & & & & & \\
\hline & SCII5 & 0.950 & & & & & & \\
\hline \multirow{5}{*}{ SCEI } & SCEI1 & 0.763 & \multirow{5}{*}{0.949} & \multirow{5}{*}{0.947} & \multirow{5}{*}{0.691} & \multirow{5}{*}{0.557} & \multirow{5}{*}{0.348} & \\
\hline & SCEI2 & 0.691 & & & & & & \\
\hline & SCEI3 & 0.769 & & & & & & \\
\hline & SCEI4 & 0.924 & & & & & & \\
\hline & SCEI5 & 0.937 & & & & & & \\
\hline \multirow{10}{*}{ LOP } & L1 & 0.779 & \multirow{10}{*}{0.897} & \multirow{10}{*}{0.950} & \multirow{10}{*}{0.777} & \multirow{10}{*}{0.523} & \multirow{10}{*}{0.366} & \multirow{10}{*}{0.55} \\
\hline & $\mathrm{L} 2$ & 0.773 & & & & & & \\
\hline & L3 & 0.944 & & & & & & \\
\hline & L4 & 0.911 & & & & & & \\
\hline & L5 & 0.768 & & & & & & \\
\hline & L6 & 0.944 & & & & & & \\
\hline & L7 & 0.934 & & & & & & \\
\hline & L8 & 0.851 & & & & & & \\
\hline & L9 & 0.877 & & & & & & \\
\hline & $\mathrm{L} 10$ & 0.849 & & & & & & \\
\hline \multirow{6}{*}{ QPM } & QIR1 & 0.951 & \multirow{6}{*}{0.911} & \multirow{6}{*}{0.944} & \multirow{6}{*}{0.599} & \multirow{6}{*}{0.526} & \multirow{6}{*}{0.343} & \multirow{6}{*}{0.59} \\
\hline & QIR2 & 0.727 & & & & & & \\
\hline & QIR3 & 0.849 & & & & & & \\
\hline & QIR4 & 0.737 & & & & & & \\
\hline & QIR5 & 0.927 & & & & & & \\
\hline & QIR6 & 0.973 & & & & & & \\
\hline \multirow{6}{*}{ IMP } & QER1 & 0.773 & \multirow{6}{*}{0.895} & & & & & \\
\hline & QER2 & 0.917 & & & & & & \\
\hline & QER3 & 0.921 & & 081 & 0573 & & & \\
\hline & QER4 & 0.688 & & 0.881 & $0.5 / 3$ & 0.527 & 0.478 & 0.56 \\
\hline & QER5 & 0.777 & & & & & & \\
\hline & QER6 & 0.791 & & & & & & \\
\hline
\end{tabular}

Model inner consistency evaluated utilizing composite unwavering quality (CR), which speaks to the extent of measure change ascribed to the hidden attribute for every originally requested build utilized in the model. All the composite dependability esteems extended from 0.877-0.950, which surpasses the suggested level 0f 0.7 (Gefen, Straub, and Boudreau, 2000; Hair, et al., 2013), this shows that sufficient consistency and the model can be viewed as solid. To check the build legitimacy a confirmatory factor analysis (CFA) has been utilized. In the event that the normal change extricated (AVE) surpasses the squared relationships, at that point separate legitimacy is set up (Fornell and larcker, 1981). An appeared in 
Table 2, the AVE esteems went from 0.573-0.777 are for the most part higher than the squared connections among the builds (off-corner to corner), and more noteworthy than the limit level of 0.5 proposed by Bagozzi and Yi, (2012) and Fornell and larcker, (1981). As appeared in Table 3, most extreme shared difference (MSV) and normal shared fluctuation (ASE) is not exactly normal change separated (AVE), which offers extra help for segregate legitimacy (Hair et al., 2013). For all develops, the estimations of these figures, which were inside the suggested levels, show a satisfactory concurrent legitimacy.

\subsubsection{Model goodness-of-fit}

There are different ways used to gauge the "goodness-of-fit" of the proposed SEM model. The proportions of the "goodnessof-fit" separated into three measures: absolute fit, incremental fit, and parsimonious fit (Hair et al., 2013). In this research, 12 records were utilized as obvious in Table 3, which are usually utilized by scientists (Hair et al., 2013).

Table 3

Structural Model Goodness-Of-Fit Indices

\begin{tabular}{|c|c|c|c|}
\hline Measures & & Value & Threshold \\
\hline \multirow{6}{*}{ Absolute fit } & Chi-square likelihood ratio & 749.34 & \\
\hline & p-value & 0.000 & \\
\hline & Degree of freedom & 293 & \\
\hline & Normed chi-square & 2.557 & $\leq 3$ \\
\hline & Goodness-of-Fit Index (GFI) & 0.937 & $\geq 0,08$ or 0.09 \\
\hline & Root mean squared error of approximation (RMSEA) & 0.053 & $\leq 0.08$ \\
\hline \multirow{6}{*}{ Incremental fit } & Tucker-Lewis Index (TLI) & 0.971 & 0.95 and above \\
\hline & Normal Fit Index (NFI) & 0.935 & 0.9 and above \\
\hline & Non-Normal Fit Index (NNFI) & 0.952 & 0.9 and above \\
\hline & Comparative Fit Index (CFI) & 0.947 & 0.9 and above \\
\hline & Incremental Fit Index (IFI): & 0.951 & 0.9 and above \\
\hline & Relative Fit Index (RFI) & 0.938 & 0.9 and above \\
\hline \multirow{2}{*}{ Parsimonious fit } & Parsimonious Normed Fit Index (PNFI) & 0.774 & 0.5 and above \\
\hline & Parsimonious Goodness-of-Fit Index (PGFI) & 0.695 & 0.5 and above \\
\hline
\end{tabular}

The outcomes showed up in Table 4 show that the entirety of the proportions of 'integrity of-fit' records were awesome and happy with the suggested qualities. Consequently, these measures demonstrated that this model was worthy and very much created

\subsubsection{Predictive Power of Model}

The prescient intensity of a model can be surveyed by assurance coefficient R2 esteems, which demonstrates the measure of fluctuation in the outcome that is clarified by the model (Haier et al., 2013). As appeared in Table 3, the model can clarify $55 \%$ of the fluctuation in lean manufacturing $(\mathrm{R} 2=0.55), 59 \%$ of the difference in quality performance measures $(\mathrm{R} 2=$ $0.59)$, and $56 \%$ of the change in stock management performance $(\mathrm{R} 2=0.56)$. Accordingly, the subsequent assurance coefficients' (R2) underlines the way that lean operations and operational performance could be impacted by different factors notwithstanding those in the model. The auxiliary model outcomes are appeared in Figure 2.

\subsection{Hypotheses testing}

The essentialness and importance of the auxiliary model were surveyed through PLS/bootstrapping strategy. Table 5, speaks to the consequences of testing the auxiliary connections of the study model.

\subsubsection{Supply Chain Internal Integration}

Theory (H1a), was upheld, the outcomes appeared in Table 5, demonstrate that supply chain interior integration has factually noteworthy impact $(\mathrm{t}=5.373 ; \mathrm{p}<0.05)$ in quality performance measures $(\beta=0.274)$, which suggests to acknowledge the elective speculation (H1a) that supply chain inner integration influences quality performance measures. Theory (H4a), was upheld since factual outcomes demonstrate that lean operations moderate the impact of supply chain inward integration in quality performance measures $(\beta=0.267 ; \mathrm{t}=5.235 ; \mathrm{p}<0.01)$. Theory $(\mathrm{H} 1 \mathrm{~b})$, was upheld, the outcomes appeared in Table 4, demonstrate that supply chain inward integration has factually huge impact $(\mathrm{t}=3.787, \mathrm{p}<0.05)$ in stock management performance $(\beta=0.178)$, which infers to acknowledge the elective speculation $(\mathrm{H} 1 \mathrm{~b})$ that supply chain interior integration influences stock management performance. Theory $(\mathrm{H} 4)$, was upheld since measurable outcomes demonstrate that lean operations moderate the impact of supply chain inner integration in stock management performance $(\beta=0.283 ; \mathrm{t}=5$.896; $\mathrm{p}<0.05)$

\subsubsection{Supply Chain External Integration}

Speculation (H1c), was upheld, the outcomes appeared in Table 4, show that supply chain outside integration has a measurably critical impact $(\mathrm{t}=6.295, \mathrm{p}<0.01)$ in quality performance measures $(\beta=0.277)$, which infers to acknowledge the elective theory $(\mathrm{H} 1 \mathrm{c})$ that supply chain outer integration influences quality performance measures. Theory (H4c), was upheld since factual outcomes demonstrate that lean operations moderate the impact of supply chain outside integration in quality performance measures $(\beta=0.234 ; \mathrm{t}=6.32 ; \mathrm{p}<0.01)$. Theory $(\mathrm{H} 1 \mathrm{~d})$, was upheld, since the outcomes appeared in Table 4 , show that supply chain outside integration has factually critical impact $(\mathrm{t}=4.849, \mathrm{p}<0.01)$ in stock management 
performance $(\beta=0.257)$, which infers to acknowledge the elective speculation (H1d) that supply chain outer integration influences stock management performance. Speculation (H4d), was upheld since factual outcomes show that lean operations moderate the impact of supply chain outer integration in stock management performance $(\beta=0.255 ; \mathrm{t}=5.795 ; \mathrm{p}<0.05)$.

\subsubsection{Supply Chain Integration - Lean Operations}

Speculation (H2a), was upheld, the outcomes appeared in Table 4, show that supply chain inner integration has factually noteworthy impact $(\mathrm{t}=11.258 ; \mathrm{p}<0.05)$ in lean operations $(\beta=0.349)$, which infers to acknowledge the elective theory $(\mathrm{H} 3)$ that supply chain interior integration influences Lean operations. Theory (H2b), was upheld, the outcomes appeared in Table 4 , demonstrate that supply chain outside integration has factually huge impact $(\mathrm{t}=3.5 ; \mathrm{p}<0.01)$ in lean operations $(\beta=0.196)$, which infers to acknowledge the elective speculation (H4) that supply chain outer integration influences Lean operations.

\subsubsection{Lean Operations - Operational Performance}

Theory (H3a), was upheld, the outcomes appeared in Table 4, show that lean activity has factually noteworthy impact $(\mathrm{t}=5.34 ; \mathrm{p}<0.05)$ in quality performance measures $(\beta=0.251)$, which infers to acknowledge the elective speculation $(\mathrm{H} 3)$ that lean operations influence quality performance measures. Speculation $(\mathrm{H} 3 \mathrm{~b})$, was upheld, the outcomes appeared in Table 4, demonstrate that lean operations have factually noteworthy impact $(\mathrm{t}=5.563 ; \mathrm{p}<0.01)$ in stock management performance $(\beta=0.278)$, which suggests to acknowledge the elective theory $(\mathrm{H} 3)$ that lean operations influence stock management performance.

Table 4

Standardized Direct and Indirect Effect

\begin{tabular}{lllll}
\hline Direct Effect & & & & \\
Hypothesis & Path coefficient $(\beta)$ & $\begin{array}{l}\text { Standard bootstrap results } \\
\text { Standard error }\end{array}$ & t-value & Sig. \\
\hline SCII - QPM & 0.274 & 0.051 & 5.373 & $0.00^{* * *}$ \\
SCII - IMP & 0.178 & 0.047 & 3.787 & $0.00^{*}$ \\
SCEI - QPM & 0.277 & 0.044 & 6.295 & $0.00^{* *}$ \\
SCEI - IMP & 0.257 & 0.053 & 4.849 & $0.00^{* *}$ \\
SCII - LOP & 0.349 & 0.031 & 11.258 & $0.00^{*}$ \\
SCEI - LOP & 0.196 & 0.056 & 3.500 & $0.0^{* *}$ \\
LOP - QMP & 0.251 & 0.047 & 5.340 & $0.00^{*}$ \\
LOP - IMP & 0.278 & 0.049 & 5.673 & $0.00^{*}$ \\
Indirect Effect & & & & \\
SCII - LOP - QMP & 0.267 & 0.051 & 5.235 & \\
SCII - LOP - IMP & 0.283 & 0.048 & 5.896 & $0.00^{* *}$ \\
SCEI - LOP - QPM & 0.234 & 0.037 & 6.32 & $0.00^{*}$ \\
SCEI - LOP - IMP & 0.255 & 0.044 & 5.795 & $0.00^{* *}$ \\
\hline
\end{tabular}

Notes: $* \mathrm{p}<0.05 ; * * \mathrm{p}<0.01 ; * * * \mathrm{p}<0.001$ (two-tailed).

\section{Results and discussion}

In the Saudi Industrial sector, manufacturing associations need more supply chain integration in order to achieve their operational performance because of the multifaceted idea of the supply chain. These manufacturing associations are joined with the world supply chain, which attempts to be especially organized. Moreover, supply chain integration practices are seen as a wellspring of focus aptitude, which prompts achieving a high ground. The delayed consequences of this research insist the valuable result of the level of all pieces of supply chain integration on operational performance in explored associations. Which maintain various disclosures came to by various specialists who went after supply chain integration (Van der Vaart et al., 2007; Flynn et al., 2010; Alfalla-Luque et al., 2013; Wong et al. 2015; Amadi-Echendu and Krüger, 2016; Chang et al., 2016; Rajaguru and Matanda, 2018; Alsafadi et al., 2020; Huo et al., 2013). The outcomes affirm the study presumptions that supply chain inward and outside integration can upgrade organizations' operational performance through lean operations. The cooperation in the supply chain permits manufacturing organizations to perceive the customers' needs and to react precisely to these requirements. So also, teammates who set up mutually lean operations can limit supply chain interruptions and rapidly react to changes in market request. This is viewed as an upper hand for the manufacturing organizations given the high condition's vulnerability of car, aviation, gadgets, and material enterprises: item change and development, material and data streams intricacy (Just-in-time), and business measure multifaceted nature. Also, the situation of these manufacturing organizations on the planet supply chain includes more supply chain integration and subsequently more inside and outside integration. This is the motivation behind why outside integration affects operational performance. Albeit inside integration has a noteworthy impact, its result is still little contrasted and outside integration. Lean operations mediation has expanded the impact of interior integration on operational performance contrasted and outside integration; this is on the grounds that lean practices focus on inside exercises (Aljawarneh et al., 2020). Accordingly, supply chain integration association with operational performance includes more lean operations exercises. This cooperation encourages producers to expand provider integration. The observational consequences of this study affirmed the positive and critical relationship between supply chain integration and the operational performance of Saudi manufacturing organizations, which uphold discoveries by past researches (Yu et al., 2013, Alfalla-Luque, et al., 2015). 


\section{Summar and Implications}

This study has endeavord to research the immediate impacts of supply chain integration (inside and outer integration) in operational performance (quality performance measures and stock management performance). The immediate impacts of supply chain integration (inward and outside integration) in lean operations, the immediate impact of lean operations in operational performance, and the directing impact of lean operations between supply chain integration and operational performance. The most responsibilities of this research are that it revealed lean operations accept an enormous part in coordinating the effect of supply chain integration on operational performance, especially for supply chain internal integration. The revelations of this research work show that supply chain integration influences operational performance. Specifically, to the extent sway in quality performance measures, it is found that supply chain outside integration has a more conspicuous effect more than supply chain internal integration. As for the effect of supply chain integration in stock administration performance, it is found that supply chain outside integration has a more noticeable effect more than supply chain inside integration. Consequently, the supply chain external integration incredibly influences operational performance more than supply chain internal integration. The revelations also show that lean action has a coordinating part between supply chain integration and operational performance, the eventual outcomes of testing the coordinating effect demonstrated that lean operations increase the effect of supply chain inside integration in quality performance checks more than the effect of supply chain outside integration. Besides, the results show that lean operations increase the effect of supply chain internal integration in stock administration performance more than the effect of supply chain outside integration. Thusly, lean operations have a coordinating capacity in the effect of supply chain integration and operational performance, favor the supply chain inside integration, which has a more unmistakable effect in operational performance more than supply chain external integration. The outcomes demonstrated that supply chain integration significantly affects lean operations, which implies that supply chain integration is bound to improve lean operations. The outcomes demonstrated that lean operations have a huge impact in operational performance, which implies that applying lean operations is bound to add to utilizing the operational performance, regardless of whether through quality performance measures, or stock management performance, or those two.

The discoveries of this study present significant ramifications for Saudi Manufacturing organizations:

1. Saudi manufacturing organizations are profoundly improved in deliberately applying supply chain integration by facilitates different business processes from upstream to downstream.

2. By executing supply chain integration, manufacturing organizations can accomplish upper hand through improve client assistance and react to advertise changes in a cost-productive way.

3. Top Management urged to perceive that objectives that may be hard to accomplish by singular organizations alone, may be accomplished through worth based supply chain connections. This needs to make worked together relations with a progression of organizations, which incorporate providers, wholesalers, and the end customers.

4. To upgrade the association's operational performance through supply chain integration, top administration should plan to arrange cross-helpful activities inside the association and effectively interface them distantly with the cycles of their partners, suppliers, and customers in the supply chain.

\section{References}

Adams, F. G., Richey Jr, R. G., Autry, C. W., Morgan, T. R., \& Gabler, C. B. (2014). Supply chain collaboration, integration, and relational technology: How complex operant resources increase performance outcomes. Journal of Business Logistics, 35(4), 299-317.

Ahmad, S., \& Schroeder, R. G. (2003). The impact of human resource management practices on operational performance: recognizing country and industry differences. Journal of operations Management, 21(1), 19-43.

Al-Bourini, F. A., Aljawarneh, N. M., Bourini, I., Almaaitah, M. F., \& kader Alomari, K. A. (2020). Directing Strategic Decision and Perceived Faculty Performance Using PLS Analysis and Monte Carlo Simulation in Jordanian Private Universities. Journal of Talent Development and Excellence, 12(3s), 2235-2252.

Al-Da'abseh, T., Aljawarneh, N., \& Shwiyat, Z. (2018). Marketing mix startegies and its impact on organizational performance efficiency in the Jordanian company for investment and supply-safeway: An empirical study. Invention Journal of Research Technology in Engineering \& Management, 2(2), 14-23.

Alfalla-Luque, R., López, C.M., \& Dey, P.K. (2013). Supply chain integration framework using literature review. Production Planning \& Control, 8-9, 800-817.

Alfalla-Luque, R., Marín-García, J., \& Medina-Lopez, C. (2015). An analysis of the direct and mediated effects of employee commitment and supply chain integration on organizational performance. International Journal of Production Economics, $162,242-257$.

Al-Jawarneh, N. M. S. (2016). Case study: Business management school at the Turkish republic of north Cyprus and how strategic thinking and planning can improve the performance of the organization to maintain stable between competitors. Invention Journal of Research Technology in Engineering \& Management (IJRTEM), 1(5), 64-72.

Aljawarneh, N. M. S., \& Atan, T. (2018). Linking tolerance to workplace incivility, Service innovative, knowledge hiding, and job search behavior: The mediating role of employee cynicism. Negotiation and Conflict Management Research, 11(4), 298320.

Aljawarneh, N. M., Sokiyna, M., Obeidat, A. M., Alomari, K. A. K., Alradaideh, A. T., \& Alomari, Z. S. (2020). The role of CRM fog computing on innovation and customer service quality: An empirical study. Marketing and Management of Innovations, 2, 286-297. 
Aljawarneh, N., \& Al-Omari, Z. (2018). The role of enterprise resource planning systems ERP in improving customer relationship management CRM: An empirical study of safeway company of Jordan. International Journal of Business and Management, 13(8), 86-100.

Al-Omari, Z. S., Aljawarneh, N., Davut, S., \& Salah, A. (2018). The impact of marketing mix elements on forming mental images about Islamic banks in Jordan: An Empirical Study. OFFICIAL, 12, 54.

Al-Omari, Z., Alomari, K., \& Aljawarneh, N. (2020). The role of empowerment in improving internal process, customer satisfaction, learning and growth. Management Science Letters, 10(4), 841-848.

Alsafadi, Y., Aljawarneh, N., Çağlar, D., Bayram, P., \& Zoubi, K. (2020). The mediating impact of entrepreneurs among administrative entrepreneurship, imitative entrepreneurship and acquisitive entrepreneurship on creativity. Management Science Letters, 10(15), 3571-3576.

Alshare, F., Aljawarneh, N., Alomari, K., Alomari, Z., Albdareen, R., AAlwagfi, A., \& Alradaideh, A. (2020). Factors influencing cellular device purchase decisions in Jordan. Management Science Letters, 10(11), 2501-2506.

Alzoubi, K., Aljawarneh, N. M., Alsafadi, Y., Al-Radaideh, A. T., \&Altahat, S. (2020). Role of cloud computing in service quality, information quality \& low costs: An empirical study on Jordanian Ccustoms. International Journal of Academic Research in Business and Social Sciences, 10(6), 522-532.

Amadi-Echendu, A.P. \& Krüger, L.P. (2016). Supply chain integration in the South African conveyancing environment, Journal of Transport and Supply Chain Management, 10(1), 1-13.

Anvari, A., Norzima, Z., Rosnay, M., Hojjati, M., \& Ismail, Y. (2010). A comparative study on journey of lean manufacturing implementation. AIJSTPME, 3, 77-85.

Ayoub, H.F., Abdallah, A.B., \& Suifan, T.S. (2017). The effect of supply chain integration on technical innovation in Jordan: the mediating role of knowledge management. Benchmarking, 24(3), 594-616.

Baird, K., Jia Hu, K., \& Reeve, R. (2011). The relationships between organizational culture, total quality management practices and operational performance. International Journal of Operations \& Production Management, 31(7), 789-814.

Banyhamdan, K. M. T., Aljawarneh, N. M., Alomari, M. A., Almasarweh, M. S., Harafsheh, I. M., \& Alwagfi, A. A. Impact of Human Capital in Quality and Strategic Excellences. International Journal of Advanced Science and Technology, 29 (7), $11702-11710$

Basnet, C., (2013). The measurement of internal supply chain integration, Management Research Review, 36(2), $153-172$.

Chang, W., Ellinger, A.E., Kim, K., \& Franke, G.R (2016). Supply chain integration and firm financial performance: A metaanalysis of positional advantage mediation and moderating factors. European Management Journal, 34(3-6), $282-229$.

Chaple1, A. P., Narkhede, \& Akarte, B. E., M. M. (2014). Status of implementation of Lean manufacturing principles in the context of Indian industry: A Literature Review, 5th International \& 26th All India Manufacturing Technology, Design and Research Conference (AIMTDR 2014) December 12th-14th, 2014, IIT Guwahati, Assam, India

Danese, P. \& Romano, P. (2010). Supply chain integration and efficiency performance: A study on the interactions between customer and supplier integration. Supply Chain Management: An International Journal, 16(4), 220-230.

Das, A., Narasimhan, R., \& Talluri, S. (2006). Supplier integration - finding an optimal configuration. Journal of Operations Management, 24(5), 563-582.

De Souza Miguel, P. L. \& Brito, L. A. L. (2011). Supply chain management measurement and its influence on operational performance. Journal of Operations and Supply Chain Management, 4(2), 56-70.

Errassafi, M., Abbar, H., \& Benabbou, Z. (2019). The mediating effect of internal integration on the relationship between supply chain integration and operational performance: Evidence from Moroccan manufacturing companies. Journal of Industrial Engineering and Management JIEM, 12(2), 254-273.

Feng, J., Prajogo, D.I., Chuan Tan, K., \& Sohal, A.S. (2006). The impact of TQM practices on performance: a comparative study between Australian and Singaporean organizations. European Journal of Innovation Management, 9(3), 269-278.

Flott, L. W. (2002). Industry in transition. Metal Finishing, 100(4), 77-82.

Flynn, B.B., Huob, B., \& Zhaod, X. (2010). The impact of supply chain integration on performance: A contingency and configuration approach. Journal of Operations Management, 28(1), January, 58-71.

Freeman, J., \& Styles, C. (2014). Does location matter to export performance?. International Marketing Review, 31(2), 181-208.

Habidin, N. F., Omar, C. M. Z. C., Kamis, H., Latip, N. A. M., \& Ibrahim, N. (2012). Confirmatory factor analysis for lean healthcare practices in Malaysian healthcare industry. Journal of Contemporary Issues and Thought, 2, 17-29.

Huang, M.C., Yen, G.F., \& Liu, T.C. (2014). Re-examining supply chain integration and the supplier's performance relationships under uncertainty. Supply Chain Management: An International Journal, 19(1), 64-78.

Huo, B., Han, Z., Zhao, X., Zhou, H., Wood, C.H., \& Zhai, X. (2013). The impact of institutional pressures on supplier integration and financial performance: evidence from China. International Journal of Production Economics, 146(1), 82-94.

Ji, H., Sui, Y., \& Wang, H. (2019). Sustainable development for shipping companies: A supply chain integration perspective. Journal of Coastal Research, SI, 98, 339-343.

Kherbach, O., Mocan, M., \& Dumitrache, C. (2017). Implementation of the lean manufacturing in local small and medium sized enterprises. Journal of Innovation Management in Small and Medium Enterprises, 1-10 OI: 10.5171/2017.799859

Lewis, M A. (2000). Lean production and sustainable competitive advantage. International Journal of Operations \& Production Management, 20(8), 959-978.

Liker, J.K., \& Wu, Y.C., (2000). Japanese automakers, US suppliers and supply-chain superiority. Sloan Management Review, 42, 81-93.

Lin, Y., \& Wu, L.-Y. (2014). Exploring the role of dynamic capabilities in firm performance under the resource-based view framework. Journal of Business Research, 67(3), 407-413.

Liu, H., Wei, S., Ke, W., Wei, K.K., \& Hua, Z. (2016). The configuration between supply chain integration and information technology competency: a resource orchestration perspective. Journal of Operations Management, 44(1), 13-29. 
Lofti, Z., Mukhtar, M., Sahran, S. \& Zadeh, A.T. (2013). Information sharing in supply chain management. Procedia Technology, 11, 298-304.

Long, Q. (2014). An agent-based distributed computational experiment framework for virtual supply chain network development. Expert Systems with Applications, 41(9), 4094-4112.

Mahafzah, A. G., Aljawarneh, N. M., Alomari, K. A. K., Altahat, S., \& Alomari, Z. S. (2020). Impact of customer relationship management on food and beverage service quality: The mediating role of employees satisfaction. Humanities \& Social Sciences Reviews, 8(2), 222-230.

Masa'd, F., \& Aljawarneh, N. (2020). Administrative creativity and job performance: An Empirical Study at Jadara University. International Journal of Psychosocial Rehabilitation. 24. 2020.

Petersen, K.J., Handfield, R.B., \& Ragatz, G.L. (2005). Supplier integration into new product development: Coordinating product, process and supply chain design. Journal of Operations Management, 23(3-4), 371-388.

Rajagopal, P., Nur Atika, Z.Z., Atika, S.B., Appasamy, G. \& Sundram, V.P.K. (2016). Determinants of supply chain responsiveness among firms in the manufacturing industry in Malaysia. International Journal of Supply Chain Management, 5(3), 18-24.

Rajaguru, R., \& Matanda, M. (2018). Role of compatibility and supply chain process integration in facilitating supply chain capabilities and organizational performance. Supply Chain Management: An International Journal, 24(2), 301-316.

Rose, A.N.M., Deros, B.M., \& Rahman, M.N.A. (2014). Critical success factors for implementing lean manufacturing in Malaysian automotive industry. Research Journal of Applied Sciences, Engineering and Technology, 8(10), 1191-1200.

Shah, R., \& Ward, T. (2007). Defining and developing measures of lean production. Journal of Operations Management, 25, 785805.

Solaimani, S., van der Veen, J., Sobek II, D. K., Gulyaz, E., \& Venugopal, V. (2019). On the application of Lean principles and practices to innovation management. The TQM Journal, 31(6), 1064-1092.

Srinivasaraghavan, J., \& Allada, V. (2006). Application of mahalanobis distance as a lean assessment metric. International Journal of Advanced Manufacturing Technology, 29, 1159-1168.

Stank, T.P., Keller, S.B., \& Daugherty, P.J. (2001). Supply chain collaboration and logistical service performance. Journal of Business Logistics, 22(1), 29-48.

Subashini, G.S., \& Kuma, S.M. (2013). An investigation on adoption of lean production principles in kitchenware manufacturing industries. Interdisciplinary Journal of Contemporary Research in Business, 4(9), 271-279.

Sundram, V. P. K., Baharin, A. S., Abdul Munir, Z. B., \& Zolait, A. H. (2018). The effect of supply chain information management and information system infrastructure: The mediating role of supply chain integration towards manufacturing performance in Malaysia. Journal of Enterprise Information Management, 31(5), 751-770.

Tan, K.C., \& Kannan, V.J. (1998). Supply chain management: supplier performance and firm performance. International Journal of Purchasing and Materials Management, 34(3), 2-9.

Tatoglu, E., Bayraktar, E., Golgeci, I., Koh, S. L., Demirbag, M. \& Zaim, S. (2016). How do supply chain management and information systems practices influence operational performance? Evidence from emerging country SMEs. International Journal of Logistics Research and Applications, 19(3), 181-199.

Truong, H. Q., Sameiro, M., Fernandes, A. C., Sampaio, P., Duong, B. A. T., Duong, H. H. \& Vilhenac, E. (2017). Supply chain management practices and firms' operational performance. International Journal of Quality \& Reliability Management, 34(2), 176-193.

Van der Vaart, T., Giménez, C., \& van Donk, P.D. (2007). Supply chain integration and performance: the impact of business conditions. 14th International Annual EurOMA Conference (EurOMA), 25, 6.

Vickery, S.K., Jayaram, J., Droge, C., \& Calantone, R. (2003). The effects of an integrative supply chain strategy on customer service and financial performance: an analysis of direct versus indirect relationships. Journal of Operations Management, 21(5), 523-539.

Voss, C.A., Åhlström, P., \& Blackmon, K. (1997). Benchmarking and operational performance: some empirical results. International Journal of Operations and Production Management, 17(10), 1046-1058.

Womack, J. P., Jones, D. T., \& Roos, D. (1990). The machine that changed the World: The triumph of lean production. New York, NY: Rawson Macmillan.

Wong, W.Y., Lai, K.H., \& Bernroider, W.N. (2015). The performance of contingencies of supply chain information integration: The roles of product and market complexity. International Journal of Production Economics, 165, 1-11.

Worley, J. (2004). The role of sociocultural factors in a lean manufacturing implementation. Unpublished Master Thesis, Oregon State University, Corvallis, $\mathrm{OH}$.

Yadav, O. P., Nepal, B., Goel, P. S., Jain, R., \& Mohanty, R. P. (2010). Insights and learnings from lean manufacturing implementation practices. International Journal of Services and Operations Management, 6, 398-422.

Yu, W., Jacobs, M.A., Enns, D.W., \& Enns, H. (2013). The effects of supply chain integration on customer satisfaction and financial performance: An organizational learning perspective. International Journal of Production Economics, 146(1).

Zhao, X., Xie, J., \& Zhang, W.J. (2002). The impact of information sharing and ordering coordination on supply chain performance. Supply Chain Management: An International Journal, 7(1), 24-40.

Zhao, X., Huob, B., Flynnc, B.B. and Yeung, J.H.Y. (2008). The impact of power and relationship commitment on the integration between manufacturers and customers in a supply chain. Journal of Operations Management, 26, 368-388.

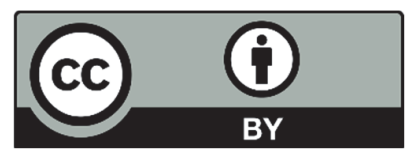

(C) 2021 by the authors; licensee Growing Science, Canada. This is an open access article distributed under the terms and conditions of the Creative Commons Attribution (CC-BY) license (http://creativecommons.org/licenses/by/4.0/). 